\title{
Figurational sociology and the rhetoric of post-philosophy
}

\section{Stephen Dunne}

University of Leicester, UK

\begin{abstract}
Norbert Elias's early work - specifically Idea and Individual - offers a positive account of philosophy's potential contribution towards a historically-oriented concrete sociological investigation. His later work, on the other hand, characterises philosophical investigation as little more than a distraction from the myth-exposing vocation of the (figurational) sociologist. This later 'post-philosophical' account of figurational sociology predominates today. Within this article, however, I suggest it has come to prominence through a series of dubious rhetorical strategies, most notably sub-textual hearsay and disingenuous caricature. By dispensing with the post-philosophical rhetoric, I argue, figurational sociologists might again, following the Elias of Idea and Individual, take the possibility of a philosophically grounded sociology seriously. If the article doesn't convince figurational sociologists to revisit philosophy as a potentially positive sociological resource, however, my effort will not have been wasted for as long as it demonstrates the presently dubious nature of their postphilosophical rhetoric.
\end{abstract}

\section{Keywords}

Norbert Elias, epistemology, Immanuel Kant, rhetoric, sociology of knowledge 


\section{Author biography}

Stephen Dunne is Lecturer in Social Theory and Consumption at the University of Leicester, School of Management. His current research analyses the relationship between the social sciences, the natural sciences and the humanities, both with and against the work of Norbert Elias. With colleagues at Leicester he is also developing a project on the role of think-tanks in general and the Mont Pelerin Society in particular. More information can be found on his departmental website http://www2.le.ac.uk/departments/management/people/sdunne.

\section{Corresponding author:}

Stephen Dunne, University of Leicester, School of Management, Ken Edwards Building, University Road, Leicester, LE1 7RH, UK.

Email: s.dunne@le.ac.uk 


\section{Figurational sociology against philosophy}

A two and a half page introduction to the turbulent life of a great thinker greets the reader of each of the already published volumes of Norbert Elias's collected works. The short piece recites a series of important dates, locations, acquaintances, difficulties, achievements and so on, generally serving to give a provisional sense for the life and work of the man - all standard fare for curtain raisers of this nature. Among the key points offered for the sake of situating this crucial sociologist's work against an appropriate historical and biographical backdrop we learn from the series editors that Elias:

wrote his doctoral thesis in philosophy, graduating in 1924, but not before having become highly critical of what he saw as the philosophers' failure to recognise the importance of the creation and transmission of knowledge as an intergenerational learning process, and ultimately rejecting philosophy as a discipline. (Norbert Elias Foundation, 2006: vii, 2005: vii and etc.)

The characterisation of Elias's work as justifiably critical of philosophy is by no means isolated to the above brief note of doubtlessly welcome contextualisation. On the contrary, it has served as one of the recurring themes through which Elias commentators have helped orientate those making their way into figurational sociology. Consider some of the more influential instances of textual evidence. Johan Goudsblom's Sociology in the Balance (1977), the earliest exclusively English book length introduction to Elias's work, polemically highlighted the need for sociologists to overcome philosophy, in the way of Elias, for the sake of maintaining their inherently precarious discipline. Stephen Mennell's Norbert Elias: An Introduction (1992: 181-199), without doubt the seminal secondary introduction to Elias's work, ${ }^{1}$ elaborated upon the rationale underpinning Elias's anti-philosophical disposition. 
More recently, Richard Kilminster's Post-Philosophical Sociology (2007) narrated Elias's project as such in terms of how it offers a justifiable break with philosophy and, more recently still, Gabriel and Mennell's Processual Thinking in Sociology again echoed the rhyme and reason characterising figurational sociology's anti-'philosophoidical' refrain (2011: 12). These four examples, of which many more could have been offered, help illustrate a point which is as clear as it is resounding: Elias's sociology has overcome philosophy and its followers must learn this crucial lesson.

This article develops an alternative account of figurational sociology's postphilosophical self-regard by opposing both the notion that Elias's work has overcome philosophy as well as the notion that such an achievement is in principle desirable. In both respects the argument which I develop here will treat Elias scholarship's post-philosophical motif as a primarily rhetorical matter, rather than as one which is grounded in robust argumentation. This involves the performance of two interrelated tasks. Firstly, it involves offering a textually supported assertion that Elias's sociology has not legitimately severed its ties from philosophy. Secondly, it involves opposing the enthusiastic subscription to the belief that Elias's work has definitively broken with philosophy with an explanation as to why this enthusiasm is presently ill-/under-advised.

To state matters more concretely: advocates of Norbert Elias's sociology routinely oppose the very suggestion that contemporary sociologists should respond to philosophical queries about their knowledge claims. This article opposes this position not because it is my intention to pedantically find flaw with it but rather because it is my intention to discuss the debilitative consequences of such a dismissive characterization of philosophy. I write neither from the perspective of a philosopher patronizingly approaching the question of sociology's 
disciplinary autonomy from the outside nor from the perspective of a rival sociological tradition's representative set on defending its own articulation of the philosophy/sociology relationship from within the confines of its own barricades. My starting point and ambitions here are a lot more modest, namely, to demonstrate how rhetorical motifs buttress the belief that figurational sociology has done away with philosophy, without its actually having done so. To call these motifs into question is not a gratuitous act of destruction, therefore. Rather, it is an attempt to resurrect a debate between philosophy and figurational sociology through a demystification of one its most persistent barriers.

If, on the other hand, it was indeed the case that Elias's work offered a definitive break with philosophy, as his advocates repeatedly claim, then we should all readily embrace the post-philosophical consequences of such a break, as described. The problem, though it need not be a terminal one, is that Eliasian scholars seem to have systematically ignored the ways in which their claim towards post-philosophical sanctuary may not actually be based upon secure foundations. More regularly, as will be demonstrated, they have devoted time and effort to outlining a defence of themselves against philosophical rebuttals on the basis of rhetorical tropes. In this article I discuss the two most persistent of these-mandarinism and homo clausus - and then go on to suggest, quite straightforwardly, that Eliasian scholars would be better advised to contemplate the possibility that their allegations against philosophy might not be well founded, rather than defiantly laboring the point that the final word, on philosophy, has long ago already been had, by sociology.

\section{History, 'the idea', Kant and community}


There is no object of historical research - so it has been argued in all these reflections - which does not confront the historian with the necessity of reflecting on the principle of his own procedure. (Elias, 2006a: 46).

With the sole exception of The Court Society (2005), the Early Writings (2006) brings together all of what Norbert Elias is currently known to have published in the quarter of a century spanning between 1914, the date of his first recorded publication, and 1939, the year in which The Civilizing Process initially appeared (Kilminster, 2006: xi). Their publication marks a crucial moment in Anglo-American Eliasian scholarship, not least of all because five of the twelve (ten substantive, two appendices) pieces gathered there are translated into English for the first time, Elias's doctoral dissertation (2006a) and his subsequent synopsis of this dissertation (2006c), most notably among them (Kilminster, 2006: xi). This section overviews these two important pieces in particular, rather than the assembled contents of the book more generally, because it is within these texts, as we have already seen above, that Elias is said to have become highly critical of philosophy. These two texts, at least if the official account is to be believed, serve to usher in an era within which an ultimate rejection of philosophy has become sanctioned. Given the stated intentions of this paper, it makes sense to closely consider the arguments they offer to this effect.

Idea and individual: a critical investigation of the concept of history, Elias's doctoral thesis, considers what, to contemporary sociological sensitivities, might seem a somewhat peculiar problem, namely, the extent to which Kantian philosophy offers an appropriate foundation for historical investigation. This basic concern doesn't seem nearly so esoteric, of course, when one takes into account the fact that Elias's dissertation supervisor, Richard Hönigswald, was a neo-Kantian philosopher and that the study was being undertaken 
precisely around a time where neo-Kantianism held powerful sway within the German university system. As we will see in the next section, the little commentary which does exist on this particular text frequently draws pronounced attention to such socio-contextual factors as a means of coming to terms with its role within figurational sociology's overall development. Once we have overviewed the argument itself we can then turn to the question of how determinative such extra-textual factors can be legitimately permitted to be.

The text begins by drawing attention to a canonical concern within historiography. On the one hand, history can simply mean all of the past - that unregulated swell and swirl of previous events, each of which has already happened. On the other hand, history can also mean the specialised mode of investigation into the seeming chaos of the past which discovers structural regularities by means of progressive self-refinement. How might we reconcile these two notions of history? The historian, for Elias, takes initial bearings from and subsequently contributes towards a constantly developing viewpoint. It is on the basis of the status of this viewpoint at a given moment that meaningful selections can be made as to 'what is historically significant' (2006a: 24). In order to know what is and is not historically significant, Elias insists, 'it is important, above all, that the historian should know what is to be understood by an "idea" (ibid.). The challenge for every historian, and hence for Elias, is to become aware of the status of 'the idea' in order to interpret the significance of any given individual historical fact upon its basis. This challenge is above all a methodological one - it is a question of how to do historical investigation:

From the solution to this problem historians may expect to gain clarity on the principle of historical selection and on the legitimacy of their own procedure, 
while philosophers may hope to gain insight into the structure of history and proof of the claim to truth which historical judgments require.

History and philosophy come together, therefore, in their common interest in the idea (Elias, 2006a: 25).

Unlike natural scientists, historians cannot justifiably fall back upon the existence of general laws (e.g. the 'law' of progress) as a means of explaining the occurrence of individual events. In rejecting the legitimacy of a natural scientific model of investigation for historical analysis, however, Elias does not deny the possibility of historical analysis as such. On the contrary, Elias addresses the theoretical challenges specific to historical analysis by basing it not upon a disciplinarily held belief in conveniently existing eternal laws but rather upon an on-going investigation into the status of 'the idea' as an inherently productive, indeed essential, endeavour (ibid.: 27). 'Dogmatic' historical analysis (unnamed 'Enlightenment' figures are accused here), must be replaced, Elias asserts, by critical historiography (ibid. 26). Therein lies the crux of Elias's dissertation project.

The term 'idea' itself 'has been bandied about too much in the course of history' (ibid.: 24), as Elias acknowledges, and it is for this reason that he turns to Kant for the sake of specification. Within Kant's philosophy, Elias underlines, the idea becomes universally determinable by virtue of the fact that the categories are proven by him to exist prior to experience. The categories, in other words, structure experience even prior to the occurrence of individual experiences (ibid.: 27). But what of the object beyond the subject's experience of it, however? That is to say, what of nature? Whereas the Critique of Pure Reason (Kant, 1998) establishes the ways in which the rationally knowable is subjectively-structurally conditioned, it simultaneously acknowledges from the outset how reason constantly seeks to 
overcome its own structurally inherent limits (Kant, 1998: 99-105). It is Kant's later critiques which demarcate and elucidate instances within which reason encounters the nonsubjectively conditioned as an object. It is this development within Kant's philosophy in particular, rather than the role of The Critique of Pure Reason within it, or even the status of Kantian philosophy more generally, that grounds Elias's dissertation's procedure. To do critical historiography, in other words, one first of all needs to study the development of the idea throughout the philosophy of Kant, beyond the first critique:

The gradually advancing severance of the idea from motifs of universality, which was brought to a relative conclusion in the Critique of Judgment, is also the task of the modern philosophy of history, if it seeks to establish a critical science of history. A study of the development of the Kantian problem of the idea would therefore directly benefit the work of systematic philosophy. (Elias 2006a: 29)

Elias's main debt to The Critique of Judgment, in particular, is to its notion of 'the purposiveness of nature' (Kant, 1987: 20-36) as a condition for the experience of nature, that is to say, to its delineation of a form of thought which establishes connections between individual events and a broader structure as such (Elias, 2006a: 30). The natural sciences demonstrably rely upon a notion of the purposiveness of nature in their descriptions of physical nature and Elias wants to demonstrate how it would be possible, in principle, for historians to perform a similar task with respect to historical nature. As we have already seen, this cannot be done by relying upon physical laws as a means of disingenuously bolstering something like a physics of history since, as Elias later on summarises, 'Unlike physical time...historical time expresses the relationship of an event to certain experiences' (2006c: 
56). Historical investigation in the scientific sense is only possible, Elias asserts, when the historian recognises from the outset how the act of attempting to connect an individual fact to a broader totality is a thoroughly dialectical process, unlike the natural sciences. That is to say:

the historian will need to understand the dialectical process of a totality when investigating an individual element within it ... the dialectical process, encompassing everything that claims validity, is that particular order through which historical facts are connected to each other; it is the order of history. (2006a: 38)

This dialectical process, as Elias calls it, is a process in which historical investigation questions the subjective and objective conditions of its own existence and the existence of that which it is treating as historically significant. This questioning initially finds the individual on the side of the subject and the idea on the side of the object. Subsequently, idea and individual become understood as two sides of the same historical process by the historian. That is to say, on the one hand, the idea is questioned by an 'I'. On the other hand, the scope for the questions asked by the questioning ' $I$ ' are determined by previous questioners - historians as well as historical figures. Elias's entire dissertation, by taking this two-sidedness of historical enquiry as a methodological problem which requires rigorous theorisation, can be understood as a demonstration of how the idea and the individual are to be understood as two sides of the same dialectical process, a process which, for him, is 'nothing other than the object of the science of history' (ibid.: 39). 
Since the object of historical research is the historical dialectical process within which a questioner comes to reconcile their own questions with a longer going tradition of questioning, the task for the historical researcher, according to Elias, is to illuminate the various dimensions of the historical dialectical process itself. Elias mentions three such dimensions and it is towards these which subsequent historical investigation, according to him, should be targeted:

Firstly, it is directed at a particular individual fact; then it has to test the idea according to which that fact has been derived and, thirdly, it has to investigate the premises of this particular concept of the idea, i.e. the premises of certain historical judgments. Only then - and precisely this is its purpose - does the historical investigation encompass the entire movement of the dialectical process. (ibid.: 44-5)

This multi-dimensional dialectical process is of interest to the philosopher as much as it is of interest to the historian. So if philosophy of history and critical historiography are to part ways, despite Elias's statement that 'history cannot be separated from philosophy' (ibid.: 47), then it certainly isn't because they have different understandings of the nature of time, of experience, or of validity (2006c: 56). Instead, as Elias observes, psychology offers a distinct but not entirely unrelated understanding of subjectivity which the historian and the philosopher, who do not so much develop a science of time as a science of the experience of time, cannot afford to ignore. What is more, if psychology indeed complicates the nature of the subjective experience of an objective structure by highlighting the role of the psyche in the structuring of experience, then the theoretical act of grounding such experience within a broader community of 'I's surely only adds additional layers of complexity to the historian's 
task (2006a: 48-51). The challenge for critical historiography, to conclude this section, is the challenge of facing up to the fact:

that all the functions of the idea must also be able to be seen as relations between 'I's, as actions, while the actions in their turn, the functions of the idea of 'community', are determined methodologically in no less manifold ways than the 'something' which the subject of the action sets as the goal of his action. The idea of community as a dimension of the idea in general makes it possible fundamentally to regard the totality of the dialectically advancing cultural areas at the same time as a totality of complexes of actions. (ibid.: 52-3).

The recognition of the predicament of the historian as one which is bound to raise issues germane to philosophy, to psychology and to differing notions of community brings Elias towards the realisation that his task, as well as the task of any critical historiography, is 'to look more deeply into the structure of society...' (ibid.: 53). It is precisely at the point at which Elias has acknowledged the sheer scope of the task facing critical historiography, and of the role played by society within it, that the manuscript regrettably breaks off.

\section{'Mandarinism' as anecdotalism}

What might Elias have gone on to say about this act of probing deeper into society for the sake of rigorously grounding historical investigation? From where might the non-dogmatic historian draw reliable empirical resources? How could Idea and Individual's demonstration that community plays an active role in the production of historical experience figure within Elias's programme of critical historiography? The premature breaking off in the 1922 manuscript begs such crucial questions, not least of all because the subsequent 1924 
summary fails to resolve them in any obvious way. We need not despair of this tantalising ellipsis, however, because we know that Elias eventually produced what can be seen as his answers in the form of figurational sociology more generally and The Civilising Process (2000) in particular. If we want to know how Elias would have brought the work he began within Idea and Individual into fruition, in other words, all we need do is read his later work.

On this account, it seems only fair to suggest that Elias's early analysis of the relationship between Kantian philosophy and historical investigation served as the foundation for his later, more celebrated work. By his initially working within Kantian philosophy, we could be forgiven for believing that Elias found a place for historical investigation and added to it an articulation of the role of community as an explicatory factor of individual and collective experience. We might then say that Elias created a conceptual and methodological edifice upon which he based the subsequent work which has gained him broad following and respect. Uncontroversial as this account of the productive role played by philosophy within the development of Elias's project might seem to the uninitiated, as well as to the author of this paper, however, it doesn't find much favour within existing commentary. ${ }^{2}$

According to Richard Kilminster, the sui generis proponent of the view that figurational sociologists owe little other than disdain to philosophy (e.g. Kilminster, 2011, 2007, 2004, 2002, 1991, 1987; Kilminster and Wouters, 1995), such an account of Idea and Individual's seemingly pro-Kantian remarks commits the error of taking them much too literally. Kilminster insists we approach Idea and Individual less with the benefit of exegetical illumination and more through the light of some not initially apparent sociocontextual factors. The remainder of this section elaborates upon this position before characterizing it less as a defensible argument and more as dogmatic rhetoric. 
Elias was rebelling against the neo-Kantians' idealism, individualism and neglect of concrete realities [A\& $\mathbf{B}]$. The institutional prominence and mandarin authority of this philosophical establishment were substantial (Köhnke 1991) $[\mathbf{A} \& \mathbf{C}] \ldots$... Elias did not attempt in the thesis to build another philosophy to replace the discredited Kantianism (as the existentialists did, for example) [B]. Rather, he embarked on the first steps of his journey towards the total rejection of philosophy itself as an intellectually credible discipline. This was, to say the least, a controversial stance and it was one that was to shape much of his later work and its reception. Even if it is not explicitly stated in the part of the manuscript which has survived, the import of Elias's argument is to cast doubt upon the status and warrant of philosophy itself [B].

Elias had to make concessions in order to satisfy Hönigswald and to secure the award of the doctorate. This accounts for the obvious contradiction between statements made in the dissertation about the dubiety of epistemological invariants and the complete endorsement of three invariants in the summary of the dissertation, published two years later... Whatever were the true facts of this matter we may never know, but the upshot of this dispute was effectively to end any possibility of Elias making a university career in philosophy at Breslau. [C] [Emphasis and annotations added] (Kilminster, 2006: xiiv-xiv)

The interpretation of Idea and Individual offered in the previous section of this paper can be said to have bracketed out the very institutional and political factors which Kilminster's account is at pains to foreground. Elias may seem to have endorsed aspects of Kantian philosophy within his doctoral dissertation, so Kilminster's sociological account of 
knowledge goes, but that is only because there are hidden factors at work there. This interpretive approach and the conclusions drawn from its application are both illuminating and compelling. Nevertheless, this mode of accounting for and dispensing with Idea and Individual's clearly pronounced pro-philosophical sentiment is ultimately unsatisfactory, I argue, for three interconnected reasons: selective subtextualism, premature rejectionism and disingenuous pragmatism (annotated, respectively, as A, B and C in the above-cited passage).

\section{A-Selective subtextualism}

To read Idea and Individual, according to Kilminster, is to read an institutionally compromised and hence radically distorted version of what Elias really wanted to argue. Elias there only endorsed Kantian philosophy in particular, and by implication philosophy in general, because he was hampered by the substantial authority of the then mandarin philosophical establishment. His entire dissertation, on this account, must be first and foremost understood as an instance of bad conscience, of institutional power-play and of opportunistic self-censorship. This amounts to drawing attention away from what Elias actually wrote for the purpose of coming to terms with what he really meant. Idea and Individual, in this sense, is actually a text written against Kantian philosophy, despite what Elias demonstrably wrote there to the contrary.

To locate Idea and Individual within the broader context of philosophical mandarinism is in keeping with Kilminster's Norbert Elias - Post-Philosophical Sociology (2007), the companion piece to his The Sociological Revolution (2002). What both books insist upon, taking their bearings directly from Elias's work more generally, is the argument that individual works - philosophical, cultural, scientific, sociological, even Elias's and 
Kilminster's own - are largely determined by the broader sociological context within which they were embedded. Kilminster puts it as follows:

it would be better for the development of sociology if sociologists were (a) to concentrate more on developing their own epistemology, concepts and methods of investigations appropriate to exploring the emergent reality of society; and (b) to distance themselves from philosophers' instructions as to how those things should or should not be done... I thus treat the academic establishment of philosophers sociologically as a structured professional group with a characteristic culture of its own, and standing for the most part higher than sociologists in the hierarchy of status and prestige of groups of scientific and other specialists. (Kilminster, 2002: 4)

Once we understand any given work as a response to the dilemmas and opportunities experienced by its author and, by extension, by a broader figuration of interdependent human beings, so the sociology of knowledge's argument goes, we gain much greater insight into it than we would have done by abstracting it from that context and engaging with it upon textual terms alone. Along these lines, Kilminster has developed his sociology of figurational sociology's opposition to philosophy (see also Goudsblom, 1987; and Gabriel and Mennell, 2011 on the sociology of figurational sociology) by accounting for the place of Idea and Individual within its overall development, along much the same lines that Elias had previously developed his sociology of courtly romantic literature (2005), of Las Meninas (1987), of Mozart (1993), and of many other things besides. ${ }^{3}$ 
Kilminster's insistence that Idea and Individual is largely determined by the context of philosophical mandarinism is an inherently Eliasian insistence: its arguments for philosophy are cloaked in mere words whereas the truth of the matter is to be found elsewhere. That the text says what it says in favour of philosophy cannot, unfortunately, be dispensed with so easily.

\section{$B$ - Premature rejectionism}

By adopting a sociological approach to knowledge we are required to become skeptical of what Elias wrote, or at least of what the early Elias has written. What we need not doubt, however, is the sociology of knowledge's insistence that Idea and Individual, 'Even if it is not explicitly stated in the part of the manuscript which has survived', casts 'doubt upon the status and warrant of philosophy itself'. That is to say, according to Kilminster, the very 'intellectual credibility' of philosophy is cast into fundamental doubt by Elias, within Idea and Individual, even if this doubt is not directly produced, or even discussed, within the text itself.

In what sense does Idea and Individual produce such doubt? Where should this doubt come from, if not from the text? What of philosophy becomes doubtful once we read Idea and Individual subtextually? How, in other words, does Idea and Individual cast doubt upon the status and warrant of philosophy, given how it is simultaneously beholden to the mandarin authority of the philosophical establishment at the time of its composition? Given how Kilminster has already hedged so much of his bets on the side of subtext, I see no obvious way out for him here. For what has he offered the reader who is not yet convinced as to the necessity of reducing text to subtext? Very little! What, moreover, does he offer the reader who does not already believe that Elias has overcome philosophy and, moreover, that 
he is right for having done so? Again, very little! None of this is to say that philosophy did not hold a dominant role when Elias was writing Idea and Individual, it is only to say that the dominance of philosophy at the time was more than a mere matter of institutional power dynamics. Idea and Individual needs to be read as something other than a Machiavellian gesture.

Consider the sheer range of what we logically cannot but dogmatically must believe in order to make it possible for Idea and Individual to have put philosophy into doubt. Firstly, we would have to believe that neo-Kantian philosophy was 'individualistic' even though Kant's moral philosophy is evidently rooted in a sense of duty to others (Kant, 1996a, 1996b, 1996c). Epistemologically, the claim also makes no sense when we realize, following the previous section, that Idea and Individual can be understood as a non-individualist instance of neo-Kantianism. Secondly, we would also have to believe neo-Kantian philosophy wasn't interested in 'concrete reality', rather than appreciating how the accessibility of reality, concrete or otherwise, was an indispensible impetus for Kantian philosophy's 'Copernican turn' (Kant, 1998: 106-124). Kant was entirely obsessed with, rather than arrogantly disinterested in, 'concrete reality', that he believed we didn't have access to it wasn't a dogmatic component of his system but a logical one. Thirdly, we would also have to believe that all Kantians were neo-Kantians, which they obviously were not (Heidegger, 1997). Finally, we would also have to believe that 'the existentialists' sought to replace a discredited Kantianism, a claim which is wrong for at least two reasons - firstly, because Kantianism was never 'discredited', at least not in this chronologically developmental sense - even Werner Heisenberg saw his work as continuous with it (1989). Secondly, it is wrong because many of the figures labeled 'the existentialists' by Kilminster demonstrably incorporated 
qualified aspects of Kantian philosophy within their systems (e.g. Heidegger, 2002; Sartre, 2002, 2001).

Kilminster wants us to believe, above all, that Idea and Individual casts doubt on the status and warrant on the intellectual credibility of philosophy. The fact is that it doesn't. All of the above notwithstanding, how could it ever be the case that Elias's supposed overcoming of neo-Kantian philosophy came to be treated as synonymous with an overcoming of philosophy as such? To overcome philosophy as such would require a systematic engagement with all philosophical systems, both past and present! Elias offers nothing of the sort, not least of all because he draws inspiration from some philosophical systems (2006d[1921]). The majority of Elias's followers neglect to engage with philosophical developments since Elias. To my mind this is not an instance of omission or idleness, it is rather the outcome of a strongly held belief in the idea that figurational sociology has already achieved a post-philosophical position.

\section{C-Disingenuous pragmatism}

Even if the above points stand, it remains clear to be seen that Elias no longer did philosophy after Idea and Individual, either in the institutional sense or in the intellectual sense. It is all good and well, therefore, to focus upon the 'true facts' that Elias didn't actually develop a definitive dismissal of (Kantian) philosophy within Idea and Individual, or that we do not actually have any textual evidence to this effect. The 'upshot' of the whole affair is what seemingly reigns paramount: Elias later on became a sociologist, rather than a philosopher, so all of the above effectively amounts to idle speculative pedantry. 
Perhaps it does. Nevertheless, intellectual conscience somehow prohibits me from agreeing with the suggestion that a post-hoc engagement with a text, guided by where it ends up rather than what it says and informed by anecdote rather than evidence, can be legitimately defended upon pragmatic grounds. Dismissing a text's demonstrable arguments in light of a supposedly realer reality induced from so called upshots is, to my mind, both inherently contentious and so obviously self-serving. Elias, it seems, abandoned philosophy for the sake of sociology and, moreover, he was right for having done so. Once you are already signed up to that argument, a disingenuous reading of Idea and Individual makes perfect sense. If you are not, it will not. The claim that figurational sociology offers a postphilosophical sociology, in this sense, is a dogmatic position which Elias and his supporters subscribe to, a predominately rhetorical gesture, the sort of thing written to the din of a guffaw and said with cheek in jowl.

\section{The arrogance of homo clausus}

In the previous section we called the belief that figurational sociology has overcome philosophy into doubt by highlighting the dubiety of the core assumptions upon which it is based. What we have not yet considered, however, is the questionability, or otherwise, of the arguments which Elias and his followers make against philosophy, for sociology. This will be our concern within the present section.

Elias's core objection to philosophy, as Stephen Mennell outlines it, is that it engages with what amounts to a false problem in the name of epistemology - the problem of thinking how it is possible for a subject to know an object, in part, or at all (Mennell, 1992: 188-193). This problem is something of a red herring, for Elias, because it is based upon a false separation of what must always be understood as interconnected aspects of a broader 
historical process: the would-be knowers and the would-be known. We cannot ever hope to understand knowledge dissemination if we believe, along with philosophers, that knowledge is an object which we, as individual subjects, are born separate from and hope to subsequently come into contact with. We must therefore abandon philosophy's false stating of the problem of knowledge, according to Elias, in order to make it possible to approach sociology's more correct one. To quote Mennell:

Elias labels this conception the homo clausus (meaning 'the closed man' or 'closed personality')...The counterpart to this conception of the isolated ego, devoid of we-images shared with fellow humans, is the implicit notion of the 'knowledgeless group' (1984a: 26ff) [1992], devoid of symbols and concepts handed down from previous generations. To all this, Elias counterposes his own conceptual starting point of homines aperti ('open people') bonded together in various ways and degrees.

In his discussion of homo clausus (1968a: 245-63 [2000]; 1970a: 119ff [1978]; 1982a: 6-17, 27-32 [1982]; 1984c: 15-16 [1984]; 1987a [1991a]) Elias enters into some detail about the varying manifestations of this static duality between 'subject' and 'object'. It is always associated with a doubt that the world 'outside', 'external reality', really exists or is as it seems [Additional bibliographic details added in parentheses]. (Mennell, 1992: 189)

What epistemology ultimately fails to consider, on the figurational account, is the inherently inter-generational and demonstrably relational character of knowledge production and dissemination, insisting instead upon a somewhat unsettling vision of isolated individual human beings, each trapped within their own discrete worlds. Wherever philosophical 
accounts of knowledge do hold sway, you can be sure - according to figurational sociologists - the image of man as homo clausus won't be too far away. As Mennell puts it: 'The pervasive influence of homo clausus is detected everywhere by Elias' (ibid.: 191). If we want to understand what knowledge actually is, and how it is actually produced, we would be better advised to take our bearings from a sociologically sensitive programme of developmental psychology, for example (ibid.: 193; see also Gabriel, 2011), rather than from the abstract and needlessly dualistic speculations of philosophy. Epistemology, on this reading, is inherently a-historical and solipsistic. Sociological theories of knowledge, on the other hand, are inherently reality-congruent.

Whilst philosophy in general is treated as guilty in this regard, it is again Kantian philosophy, in particular, which gets put upon exegetical trial. ${ }^{4}$ Underlining the crux of the problem with recourse to the claim that philosophy cannot think inter-generational knowledge transmission, whereas sociology can - or at least could - Mennell argues:

Kant, it must be remembered, like everyone else argued with a language he had learned socially. He asked 'where does my concept of “cause” come from?' He was right that he had not learned it by himself. But he had learned it from his teachers. The concept of cause was there in his society. Several generations earlier it had not been. It had gone through a long process of development in society, the intergenerational transmission of symbols slowly adding to the stock of knowledge and of the categories available for use in thinking by people in society. (1992: 193) 
In as much as this passage helps clarify the nature of Elias's reservations against philosophy, it also conveys his ability to fundamentally misrepresent Kant's project. Within the remainder of the section I will do two things about this. Firstly, I will demonstrate why the above amounts to a fundamental misrepresentation of Kant. Secondly, I will underline how Elias is more than aware of how this sort of argument amounts to a fundamental misrepresentation of Kant, yet arrogantly makes it anyway. I close the section by suggesting that the arrogance of such a self-imposed ignorance only serves to reinforce the suggestion, made in the previous section, that figurational sociology's arguments against philosophy are more dogmatic than definitive.

\section{The misrepresentation of Kant on cause}

Kant was not the first person to ask what the concept of cause was, nor was he the first to enquire where that concept came from. Speculations on causation go back to the preSocratics, at least (Kenny, 2010). Kant's own engagement was a specific response to the work which Descartes, Newton, Leibniz and above all Hume had also been doing around his time. As Kant himself puts it:

I tried first whether Hume's objection could not be put into a general form, and soon found that the connection of cause and effect was by no means the only concept by which the understanding thinks the connection of things apriori ... This deduction ... was the most difficult task ever undertaken in the service of metaphysics. (Kant, 2001: 5)

Kant is by no means blind to how the concept of cause has changed over the generations, therefore. He also knows very well that the way he thinks about cause is a by-product of the 
thinking of previous generations. Merely acknowledging how his enquiry into causation implies a longer lineage, however, wouldn't have helped Kant address the specific problems which he wanted to address - it would have simply re-stated what he already knew to have been obvious.

Let us consider the above cited passage, within which Kant puts so much stock in his attempt to rescue the concept of cause he inherited from David Hume's radical scepticism, in a little more detail. For Hume (2007, 1985), our concept of cause is derived out of our everyday habits, rather than from scientific propositions and/or metaphysical speculations. That is to say, we learn what cause is from experience: we couldn't even think in terms of cause if we hadn't first of all observed what we take to be a causal chain of occurrences. In Hume's own famous example, if I see a billiard ball strike another billiard ball, whereby the second moves on impact, and if I witness this apparent chain of events occurring often enough, I will eventually form the habit of thinking that the event of striking causes the event of movement. According to Hume, then, I induce my concept of cause from experience: by observing one billiard ball striking another one often enough I come to believe that the former event causes the latter. The sceptical aspect of Hume's philosophy is to insist that there is no necessary connection between these two events and that our knowledge of causes, or of anything else at all, is largely a matter of common sense habit borne out of every day experience. About Hume's writing on cause Kant says the following:

The question was not whether the concept of cause was right, useful, and even indispensable for our knowledge of nature, for this Hume had never doubted; but whether that concept could be thought by reason apriori, and consequently whether it possessed an inner truth, independent of all experience, implying a 
more widely extended usefulness, not limited merely to objects of experience.

This was Hume's problem. (2001: 4)

Following Hume's problem but ultimately proposing an alternative solution towards it, Kant argues that in order for us to even be able of having a concept of cause at all, it must be the case that there is something else which is apriori necessary, rather than aposteriori arbitrary, about it. It is in this sense that the 'Copernican Revolution' previously alluded towards comes into play. The whole of The Critique of Pure Reason, as Kant puts it, amounts to 'the working out of Hume's problem in its widest extent' (2001: 6). Kant's attempt to rescue knowledge from Hume's scepticism is guided by what seems a prohibitively obscure question, namely, 'How are synthetic judgments apriori possible?' (1998: 146). What this question asks after, however, becomes clearer through an engagement with the intergenerational tradition of knowledge transmission which Kant acknowledged himself to have been engaging with. Hume, Kant argues, 'among all philosophers came closest to this problem' (ibid.) which The Critique of Pure Reason discusses in intimidating detail. As Kant puts it elsewhere

I openly confess that my remembering David Hume was the very thing which many years ago first interrupted my dogmatic slumber and gave my investigations in the field of speculative philosophy a quite new direction...If we start from a well-founded, but undeveloped, thought which another has bequeathed to us, we may well hope by continued reflection to advance further than the acute man to whom we owe the first spark of light. (2001: 5) 
To bemoan Kant's inability to think cause inter-generationally is to completely miss the point of what, for many, remains the single most important contribution to the history of ideas. It fundamentally misses the point both because Kant was more than aware of the intergenerational characteristics of aposteriori knowledge acquisition and transmission, and also because he went on to demonstrate how the intergenerational production of aposteriori knowledge depended upon the scope and endurance of apriori concepts, of which cause was but one. To prioritise sociology's focus upon the intergenerational characteristics of knowledge dissemination over the supposed solipsism of Kant in particular or of philosophy in general, is to insist upon a problem which doesn't actually exist. Perhaps figurational sociologists could return to Kant for the sake of interrupting their own dogmatic slumber.

\section{The arrogance of misrepresentation}

it is more productive for the future of sociology if I go on working in the laboratory as I have done before, like a physicist who would go to his labour every day and do his stint instead of criticizing other physicists. (Elias, c.f. Kilminster, 1987: 215).

The rudimentary aspects of Kant's writing on cause noted above will be familiar to anybody who has read Kant with the intention of coming to terms with his work. Figurational sociologists rarely read philosophy with the intention of doing anything other than impatiently dismissing it for not being sociology, however, so the above account may well be news to them. It wouldn't be news to Elias himself, however, who certainly knew that a project of intergenerational knowledge transmission could be generated on the basis of Kantian principles. Idea and Individual, as we have already seen, outlined the contours of just 
such a project by demonstrating how The Critique of Judgment built upon The Critique of Pure Reason, and by embedding sociological and psychological insights into the Kantian system. That Elias eventually departed from Kant in his effort 'to look more deeply into the structure of society...' (2006a: 53) is certainly a matter of record. That Elias also ignored what he had previously demonstrated that he knew, namely, that philosophy does more than simply labour under the mistaken image of man as homo clausus, however, is also demonstrably the case.

The whole point of the homo clausus proposition, it seems to me, ultimately consists in a not very careful rhetorical disparagement of philosophy. This impatience is more a characteristic of Elias's later work, it is only as his thinking develops that his antiphilosophical resolve hardens and it is only in the hardening of this resolve that he unleashes his homo clausus caricature of philosophy. Idea and Individual can be taken as evidence for the claim that Elias knows only all too well that what he says about philosophy, in the name of homo clauses, was anything but accurate. ${ }^{5}$ The frustrating mystery is that he makes so many remarks, which he knew not to have been fair comment, yet published anyway, for primarily rhetorical effect:

a tragicomic masquerade of wasted lives, litters mankind's trail. If the world 'an sich' is unknowable, one wonders why their authors bother, often rather emphatically, to state their case. Resigned silence might be more appropriate. (1982: 104)

Or again: 
The image of human beings on which the whole fabric of philosophical epistemology rests is unsound. An ideal, that of a totally independent individual, of an 'I' without 'you' and 'we', the ideal of a passing period, is presented as if it were a timeless and universal fact. Descartes gave the signal: 'Cogito ergo sum.' What can be more absurd! Merely in order to say it, one had to learn a communal language; and why say it if no one was there to listen, to accept or reject it? (1987: xviii)

Elias is clearly something of a virtuoso in the dark art of disingenuously patronising philosophy. More often than not, however, what is better understood as battle-hardened rhetoric often ends up being treated as factual decree. This is not to say that there is absolutely no place for the banter-led parlour games of intellectual one-upmanship. It is only to say that once the fun has been had, it is important to get on with the serious work of separating the rhetoric of anti-philosophy out from the actual argument against philosophy. This rarely happens. Elias knows philosophers don't erect the false idol of homo clausus in everything that they do. When he uses the term it is clear that he is offering a rhetorical caricature of a straw-man called philosophy, rather than presenting a reliable dismissal of everything ever done in the name of philosophy. Elias, as was well known, could be a very curmudgeonly defiant writer, particularly in his later work. As Richard Kilminster puts it:

In relation to the mainstream disciplines of philosophy, psychology, and history, the factions and schools within professional sociology, as well as towards Marxism and other ideologies, Elias declares a 'plague on all your houses'. (2007: x) 
This surely means again, not as if there can be any doubt at this stage, that not all of Elias's arguments in each of these regards can be taken entirely seriously. Elias, I think, caricatured philosophical judgments as inherently mystified by the allures of homo clausus only because he no longer had the patience to seriously engage with philosophy which he once clearly had. This excessive reliance upon hubristic posturing at the expense of careful argumentation is obviously one of the most frustrating and off putting characteristics of his work. His obviously underdeveloped dismissal of philosophy is perhaps the clearest example of this.

\section{Discussion}

In one of his more modest moments, Elias highlighted the developmental nature of his own work and in so doing underlined the need for a lot more people, in a lot of different disciplines, to spend a lot more time working through the issues which it raised. Just as the civilising process is by no means complete, ${ }^{6}$ so too, Elias insisted, the arguments laid out in The Civilising Process cannot be treated as irrefutable propositions on the nature of all human societies that have anywhere ever been. The work initiated within Elias's most celebrated book, therefore, is by no means complete, rather:

It will need the thought of many people and the co-operation of different branches of scholarship, which are often divided by artificial barriers today, gradually to answer the questions that have arisen in the course of this study. They concern psychology, philology, ethnology and anthropology no less than sociology or the different special branches of historical research. (2000: xiv)

Given what we have read throughout this article, it should come as no surprise, and it was almost certainly no accident, that philosophy is omitted from this list of the requisite 
intellectual disciplines of the future. This article has attempted to suggest that this sort of omission is both gratuitous and premature. Such a wilful forgetting of philosophy, moreover, is hardly in keeping with figurational sociology's emphatic insistence upon the intergenerational processes of knowledge production and transmission (see also Elias, 1977: 67, c.f. Korte, 2001: 18 and Gabriel and Mennell, 2011). By proposing to occupy a postphilosophical sanctuary, figurational sociologists are proposing to occupy a position analogous to the hundredth floor of the Babelesque tower which Elias elsewhere offered a very strong warning against:

I once read the story of a group of people who climbed higher and higher in an unknown and very high tower. The first generation got as far as the fifth storey, the second reached the seventh, the third the tenth. In the course of time their descendants attained the hundredth storey. Then the stairs gave way. The people established themselves on the hundredth storey. With the passage of time they forgot that their ancestors had ever lived on lower floors and how they had arrived at the hundredth floor. They saw the world and themselves from the perspective of the hundredth floor, without knowing how people had arrived there. They even regarded the ideas they formed from the perspective of their floor as universal human ideas. (1992: 135)

What I have been trying to suggest throughout this article is that figurational sociology's opposition to philosophy requires re-visitation. I have spent most of my time in this regard challenging the widely held proposition that Elias's work amounts to a definitive dispensation with philosophy. To this effect I have argued that this proposition is largely rhetorical in nature, that once we pay careful attention to the textual and subtextual evidence 
for its claims, we find it severely wanting. This is not to say that figurational sociology cannot break with philosophy, it is only to say that the arguments which it has mobilised in support of this break remain debatable at best and spurious at worst. The suggestion that figurational sociology is best understood as a post-philosophical sociology amounts to an instance of the very sort of wishful thinking which Elias sought to free the sociologist from, in that figurational sociologists have ended up

believing and feeling we actually are what we ought to be and what we may even want to be. More precisely, we confuse fact with ideal, that which is with that which ought to be. (1978: 118)

This need not be the case, however. An alternative to the repetition of Elias's indiscriminate and at times vicious attacks upon philosophy would be to actually read works of philosophy, much like the early Elias used to do, in order to consider their applicability to contemporary and long-term sociological problems, or otherwise. On the other hand, if figurational sociologists believe that their professional ends aren't best served by a careful engagement with philosophy, which many clearly do, the least they could do would be to stop disingenuously denouncing one of the longest going cultural traditions which mankind has ever known with recourse to cartoon-like representations of it, and instead just get on with the work of actually doing figurational sociology. 


\section{Notes}

This article was first presented in April 2012, submitted to the conference organisers in August 2012, to this journal in October 2013 and for publication in April 2014. During March 2014, amidst final revisions, my attention was drawn to the recent publication of a text within which Elias offers retrospective reflections on his doctoral dissertation. My many and varied attempts to secure a copy of this text in time for the final submission of the present article proved futile.

I would like to thank Ruud Kaulingfreks, as always, for his many helpful suggestions on this and previous versions of the article. I would also like to thank the editors for arranging the event where this article was first presented, as well as the audience who so clearly suffered through it. Jason Hughes, in particular, offered particularly constructive feedback for which I am very much indebted. I doubt he will like what I did with his feedback though that probably goes without saying.

1. Elias's own What is Sociology? (1978), a text which Stephen Mennell himself translated, is the best primary introduction to Elias's work.

2. Harste (1994) offers a rare if not exclusive exception to the rule which would have it that Elias's sociology must be seen as a fundamental break with, rather than a subtle continuation of, Kantian philosophy in particular and philosophy more generally.

3. This is not to say that Kilminster (or Elias, for that matter) systematically avoids supporting his position with recourse to textual evidence. On the contrary, Kilminster very clearly mentions an 'obvious contradiction' which exists between Elias's dissertation and its subsequent summary. For my part I cannot see the contradiction which Kilminster is alluding towards. If it does exist, it is in a far from obvious manner. 
4. The previous section has already drawn attention to the problems inherent in this operation of mistaking parts of philosophy for the whole of philosophy.

5. This is not to say that the early Elias struggled for confidence in his observational abilities. One need only consider his earliest published sentence for evidence to the effect that this was not a man who felt he required the vindication of others: 'I shall note down anything that occurs to me as worthy of recording' (Elias, 2006e: 3).

6. As is frequently pointed out within the literature, Elias speculated that 'our descendants, if humanity can survive the violence of our age, might consider us as late barbarians' (1991b: 146-147).

\section{References}

Elias, N. (1977) 'Drake en Doughty: De ontwikkeling van een conflict [Drake and Doughty: The Development of a Conflict]', De Gids, 140(5/6): 223-237.

Elias, N. (1978) What is Sociology?, trans. S. Mennell and G. Morrissey. New York: Columbia University Press.

Elias, N. (1982) 'Scientific Establishments', in N. Elias, H. Martins and R. Whitley (eds) Scientific Establishments and Hierarchies. Dordrecht: D. Reidel Publishing Company, pp. 3-69.

Elias, N. (1984) 'Notizenzum Lebenslauf' [Notes on a Lifetime], in P. R. Gleichmann et al. (eds) Macht und Zivilization [Power and Civilization]. Frankfurt: Suhrkamp, pp. 9-82.

Elias, N. (1987) Involvement and Detachment, trans. E. Jephcott. Oxford: Basil Blackwell.

Elias, N. (1991a) The Society of Individuals, trans. E. Jephcott, Oxford: Basil Blackwell.

Elias, N. (1991b) The Symbol Theory. London: Sage.

Elias, N. (1992) Time: An Essay, trans. E. Jephcott, Oxford: Basil Blackwell. 
Elias, N. (1993) Mozart: Portrait of a Genius, trans. E. Jephcott, Cambridge: Polity Press.

Elias, N. (2000) The Civilizing Process - Sociogenetic and Psychogenetic Investigations, trans. J. Goudsblom. Oxford: Blackwell.

Elias, N. (2005) The Collected Works of Norbert Elias (Volume Two: The Court Society), trans. E. Jephcott. Dublin: UCD Press.

Elias, N. (2006a) 'Idea and Individual: A Critical Investigation of the Concept of History', in The Collected Works of Norbert Elias (Volume One: Early Writings), trans. E. Jephcott. Dublin: UCD Press, pp. 23-54.

Elias, N. (2006b) The Collected Works of Norbert Elias (Volume One: Early Writings), trans. E. Jephcott. Dublin: UCD Press.

Elias, N. (2006c) 'Idea and Individual: A Contribution to the Philosophy of History', in The Collected Works of Norbert Elias (Volume One: Early Writings), trans. E. Jephcott. Dublin: UCD Press, pp. 55-58.

Elias, N. (2006d[1921]) 'On Seeing in Nature', in The Collected Works of Norbert Elias (Volume One: Early Writings), trans. E. Jephcott. Dublin: UCD Press, pp. 5-22.

Elias, N. (2006e) 'Three-day Excursion to the Riesengebirge', in The Collected Works of Norbert Elias (Volume One: Early Writings), trans. E. Jephcott. Dublin: UCD Press, pp. 3-4.

Gabriel, N. (2011) 'Norbert Elias and Developmental Psychology', in N. Gabriel and S. Mennell (eds) Norbert Elias and Figurational Research: Processual thinking in Sociology. Oxford: Blackwell, pp. 202-219.

Gabriel, N. and Mennell, S. (2011) 'Handing over the Torch: Intergenerational Processes in Figurational Sociology', in N. Gabriel and S. Mennell (eds) Norbert Elias and Figurational Research: Processual thinking in Sociology. Oxford: Blackwell, pp. 523. 
Goudsblom, J. (1977) Sociology in the Balance: A Critical Essay. Oxford: Blackwell.

Goudsblom, J. (1987) 'The Sociology of Norbert Elias: Its Resonance and Significance', Theory, Culture \& Society 4: 323-337.

Harste, G. (1994) 'The Definition of Organisational Culture and its Historical Origins', History of European Ideas 19(1-3): 3-15.

Heidegger, M. (1997) Kant and the Problem of Metaphysics (Fifth Edition), trans. R. Taft. Indianapolis: Indiana University Press.

Heidegger, M. (2002) The Essence of Human Freedom, trans. T. Sadler. London: Continuum. Heisenberg, W. (1989) Physics and Philosophy. London: Penguin.

Hume, D. (1985) A Treatise of Human Nature. London: Penguin.

Hume, D. (2007) An Enquiry Concerning Human Understanding. London: Penguin.

Kant, I. (1987) Critique of Pure Judgment, trans. W. S. Pluhar. Indianapolis: Hackett.

Kant, I. (1996a) 'Groundwork of the Metaphysics of Morals', in Practical Philosophy, trans. M. J. Gregor. Cambridge: Cambridge University Press, pp. 37-108.

Kant, I. (1996b) 'Critique of Practical Reason', in Practical Philosophy, trans. M. J. Gregor. Cambridge: Cambridge University Press, pp. 133-272.

Kant, I. (1996c) 'The Metaphysics of Morals', in Practical Philosophy, trans. M. J. Gregor. Cambridge: Cambridge University Press, pp. 353-604.

Kant, I. (1998) Critique of Pure Reason, trans. P. Guyer and A. W. Wood. Cambridge: Cambridge University Press.

Kant, I. (2001) Prolegomena to Any Future Metaphysics (Second Edition), trans. P. Carus and J. W. Ellington. Indianapolis: Hackett.

Kenny, A. (2010) A New History of Western Philosophy. Oxford: Oxford University Press.

Kilminster, R. (1987) 'Introduction to Elias', Theory, Culture \& Society 4: 213-222.

Kilminster, R. (1991) ‘Evaluating Elias', Theory, Culture \& Society 8: 165-176. 
Kilminster, R. (2002) The Sociological Revolution: From the Enlightenment to the Global Age. London: Routledge.

Kilminster, R. (2004) 'From Distance to Detachment: Knowledge and Self-Knowledge in Elias's Theory of Involvement and Detachment', in S. Loyal and S. Quilley (eds) The Sociology of Norbert Elias. Cambridge: Cambridge University Press, pp. 25-41.

Kilminster, R. (2006) 'Note on the Text' in The Collected Works of Norbert Elias (Volume One: Early Writings), trans. E. Jephcott. Dublin: UCD Press, pp. xi-xx.

Kilminster, R. (2007) Norbert Elias: Post Philosophical Sociology. Oxford: Routledge.

Kilminster, R. (2011) 'Norbert Elias's Post-philosophical Sociology: From 'Critique' to Relative Detachment' in N. Gabriel and S. Mennell (eds) Norbert Elias and Figurational Research: Processual thinking in Sociology. Oxford: Blackwell, pp. 91116.

Kilminster, R. and Wouters, C. (1995) 'From Philosophy to Sociology: Elias and the NeoKantians (a response to Benjo Maso)', Theory, Culture \& Society 12: 81-120.

Kohnke, K. C. (1991) The Rise of Neo-Kantianism: German Academic Philosophy Between Idealism and Positivism, trans. R. J. Hollingdale. Cambridge: Cambridge University Press.

Korte, H. (2001) 'Perspectives on a Long Life: Norbert Elias and the Process of Civilization', in T. Salumets (ed.) Norbert Elias and Human Interdependencies. London: McGillQueen's University Press, pp. 13-31.

Mennell, S. (1992) Norbert Elias: An Introduction. Dublin: UCD Press.

Norbert Elias Foundation (2005) 'Norbert Elias 1897-1990', in The Collected Works of Norbert Elias (Volume Two: The Court Society), trans. E. Jephcott. Dublin: UCD Press, pp. vii-ix 
Norbert Elias Foundation (2006) 'Norbert Elias 1897-1990', in The Collected Works of Norbert Elias (Volume One: Early Writings), trans. E. Jephcott. Dublin: UCD Press, pp. xi-xx.

Sartre, J.-P. (2001) What is Literature?, trans. B. Frechtman. London: Routledge.

Sartre, J.-P. (2002) Being and Nothingness: An Essay on Phenomenological Ontology, trans. H. E. Barnes. London: Routledge. 